DOI: 10.36695/2219-5521.1.2020.68

УДК 343

\title{
А.І. Шкодяк
}

Альона Ігорівна Шкодяк, аспірант Львівського національного університету імені Івана Франка*

ORCID: 0000-0001-7598-4778

\section{КРИМІНАЛЬНО-ПРАВОВА ОЦІНКА ПОРУШЕННЯ ПРАВИЛ ПРОВЕДЕННЯ КЛІНІЧНИХ ДОСЛІДЖЕНЬ ЛІКАРСЬКИХ ЗАСОБІВ}

Постановка проблеми. Розвиток медичних досліджень тісно пов'язаний із дослідженнями у фармацевтичній сфері. Одним із етапів розробки та випуску на фармацевтичний ринок нових лікарських препаратів $є$ проведення клінічних досліджень за участю досліджуваних-добровольців. Кримінальний кодекс України встановлює відповідальність за порушення норм та процедур проведення клінічних досліджень лікарських засобів у двох статтях кодексу. Яка їх суть і чи дійсно існує необхідність в існуванні цих двох норм, буде розглянуто в цій статті.

Аналіз останніх досліджень і публікацій. Оскільки кримінально-правовій характеристиці злочинів, що пов'язані із проведення клінічних досліджень лікарських засобів, не було присвячено публікацій, це дослідження базується на аналізі галузевих нормативно-правових актів та коментованому Кримінальному кодексі України.

Мета статті - надати кримінально-правову характеристику злочинам, що можуть бути вчинені під час проведення клінічних досліджень лікарських засобів.

Виклад основного матеріалу. Проведення клінічних досліджень лікарських засобів є важливим етапом при створенні та випуску на фармацевтичний ринок лікарських засобів. Одним із заходів забезпечення дотримання норм у цій сфері є встановлення кримінальної відповідальності за їх порушення. Отже, законодавець передбачив декілька статей у Кримінальному Кодексі України (далі - КК України), які стосуються діяльності у фармацевтичній сфері. Зупинимо свою увагу на двох із них.

Першою є ст. 141 КК України з назвою «Порушення прав пацієнта». Вона встановлює відповідальність за проведення клінічних випробувань лікарських засобів без письмової згоди пацієнта або його законного представника, або стосовно неповнолітнього чи недієздатного, якщо ці дії спричинили смерть пацієнта або інші тяжкі наслідки 1 . Оскільки ця норма має бланкетний характер, для тлумачення ознак цього складу злочину потрібно буде звернутися до нормативно-правових актів, які регулюють проведення клінічних дослідів лікарських засобів. Отже, розглянемо елементи цього складу злочину.

Основним безпосереднім об'єктом складу злочину, передбачено в ст. 141 КК України, є життя та здоров'я особи, щодо якої проводиться клінічне випробування лікарських засобів, а його додатковим обов'язковим об 'єктом - порядок проведення клінічних випробувань лікарських засобів ${ }^{2}$. Порядок проведення клінічних випробувань лікарських засобів регулюється такими нормативно-правовими актами, як: Конституція України, Цивільний кодекс України (далі - ЦК України), Закон України «Основи законодавства України про охорону здоров'я», Закон України «Про лікарські засоби», Наказ Міністерства охорони здоров'я України № 690 від 23 вересня 2009 р. «Про затвердження Порядку проведення клінічних випробувань лікарських засобів та експертизи матеріалів клінічних випробувань і Типового положення про комісії з питань етики» (далі - Наказ MO3 № 690).

Об 'єктивна сторона ст. 141 КК України характеризується такими ознаками: 1) дії у вигляді проведення клінічних випробувань лікарських засобів: а) без письмової згоди пацієнта чи його законного представника; б) щодо неповнолітнього чи недієздатної особи; 2) наслідками у вигляді смерті чи інших тяжких наслідків (під якими у цій статті розуміють тяжкі тілесні ушкодження або середньої тяжкості тілесні ушкодження); 3) причинним зв'язком між проведенням клінічних випробувань та наслідками ${ }^{3}$ Відповідно до Наказу МО3 № 690 клінічне випробування (дослідження) лікарського засобу - це науково-дослідницька робота, метою якої є будь-яке дослідження за участю людини як суб'єкта дослідження, призначене для виявлення або підтвердження клінічних, фармакокінетичних, фармакодинамічних та/або інших ефектів, у тому числі для вивчення усмоктування, розподілу, метаболізму та виведення одного або кількох лікарських засобів та/або виявлення побічних реакцій на один або декілька досліджуваних лікарських засобів 3 метою оцінки його (їх) безпечності та/або ефективності. Досліджуваним (суб'єктом дослідження) є пацієнт (здоровий доброволець), який згідно з чинним законодавством бере участь у клінічному випробуванні4. 3'ясуємо більш детально питання особи досліджуваного та які передумови передбачає чинне законодавство для його участі в таких дослідах.

Конституція України в ст. 28 передбачає, що «жодна людина без їі вільної згоди не може бути піддана медичним, науковим чи іншим дослідам» ${ }^{5}$. Стаття 45 Закону України «Основи законодавства України про охорону здоров'я» встановлює принципи проведення медико-біологічних експериментів на людях (до яких

(C) A.I. Шкодяк, 2020

* Alona Shkodiak, Ph.D. Student of Ivan Franko National University of Lviv 
відносять і клінічні дослідження лікарських засобів), одним із яких є повна інформованість і вільна згода повнолітньої дієздатної фізичної особи, яка підлягає експерименту, щодо вимог застосування експериментуб. ЦК України наголошує, що медичні, наукові та інші досліди можуть проводитися лише щодо повнолітньої дієздатної фізичної особи за їі вільної згоди (ч. 3 ст. 281)7. Виходячи 3 аналізу норм цих законів, досліджуваним може бути лише повнолітня дієздатна особа, яка надала письмову згоду на участь у дослідженні.

Спеціальними нормативно-правовими актами, що регулюють проведення клінічних випробувань лікарських засобів, є Закон України «Про лікарські засоби» і Наказ МОЗ № 690. Вони також передбачають, що клінічні випробування можуть проводитися за участю повнолітньої дієздатної особи - пацієнта (добровольця) у разі наявності їі письмової згоди на участь у проведенні таких випробувань. Однак, поруч із цією категорією досліджуваних, Закон України «Про лікарські засоби» передбачає в ст. 8, що до клінічних випробувань можуть бути залучені малолітні, неповнолітні особи, особи, які судом визнані недієздатними або цивільна дієздатність яких обмежена у зв'язку із психічними захворюваннями. Малолітні особи можуть бути залучені до клінічних досліджень у разі наявності письмової згоди батьків малолітньої особи, за умови надання малолітньому інформації про дослідження в доступній для нього формі. Неповнолітня особа залучається до досліджень при наявності ії письмової згоди та письмової згоди іії батьків. Про проведення клінічних дослідів щодо цих категорій осіб обов'язково мають бути повідомлені органи опіки та піклування за місцем постійного проживання цих осіб. Ці дві категорії осіб можуть бути залучені до клінічних випробувань $з$ метою оптимізації дозування чи режиму застосування лікарського засобу після завершення клінічних випробувань цих лікарських засобів за участю повнолітніх дієздатних осіб; якщо випробування стосується захворювань, від яких страждають малолітні та неповнолітні діти; планування клінічних випробувань здійснено таким чином, що мінімізовані біль, дискомфорт, страх і ризик (ч. 2, 3,4 ст. 8 Закону України «Про лікарські засоби»). Щодо проведення клінічних випробувань за участю особи, яка визнана судом недієздатною або цивільна дієздатність якої обмежена у зв'язку з психічним захворюванням, то такі дослідження щодо них можуть проводитися лише у випадках, якщо лікарський засіб призначений для лікування психічних захво-

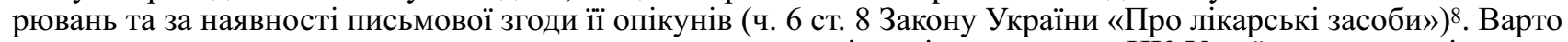
зауважити, що тут законодавець припустився помилки: відповідно до норм ЦК України лише недієздатна особа має опікуна; особі, цивільна дієздатність якої обмежена, призначається піклувальник.

Наказ MO3 № 690, який встановлює вимоги до проведення клінічних випробувань лікарських засобів, передбачає такі категорії досліджуваних, як: 1) повнолітні дієздатні особи; 2) малолітні особи; 3) неповнолітні особи; 4) недієздатні особи․ Наказ МО3 № 690 жодним чином не згадує про осіб, цивільна дієздатність яких обмежена у зв'язку із психічним захворюванням. Тобто відсутня прописана процедура щодо проведення клінічних досліджень лікарських засобі із залученням осіб, дієздатність яких обмежена, хоча Закон України «Про лікарські засоби» допускає їхню участь. Тому виникає питання щодо можливості залучення таких осіб до проведення клінічних досліджень.

Однак повернемося до об'єктивної сторони ст. 141 КК України. Виходячи з дослівного тлумачення диспозиції ст. 141, можна виокремити два альтернативні діяння: 1) проведення клінічних досліджень без письмової згоди пацієнта або його законного представника, які спричинили наслідки у вигляді смерті або інших тяжких наслідків; 2) проведення клінічних випробувань лікарських засобів щодо неповнолітньої або недієздатної особи, які спричинили наслідки у вигляді смерті або інших тяжких наслідків ${ }^{10}$. Тобто якщо в першому випадку законодавець ставить у залежність притягнення до кримінальної відповідальності до наявності письмової згоди (за умови настання наслідків), то у випадку з неповнолітньою/недієздатною особою наявність чи відсутність письмової згоди від цих осіб/іх законних представників на участь у клінічних дослідження не відіграє жодної ролі. Таке формулювання законодавцем диспозиції ст. 141 можна розцінити як привілейоване ставлення до цих двох категорій осіб, які в силу свого статусу потребують підвищеного рівня охорони.

Під письмовою згодою варто розуміти оформлену відповідним документом, що має підпис пацієнта, згоду, яку він надав добровільно, без будь-якого примусу11. Вимоги до письмової згоди досліджуваного щодо клінічного випробування лікарського закладу передбачені Додатком 2 до Порядку проведення клінічних випробувань лікарських засобів та експертизи матеріалів клінічних випробувань Наказу МО3 № 690 (тут вона позначається як «інформована згода»). Отриманню письмової згоди передує інформування досліджуваного (або його законних представників) у доступній для нього формі щодо всіх аспектів клінічного випробування та укладення договору стахування життя і здоров’я досліджуваного.

Диспозиція ст. 141 КК України передбачає обов'язкове настання наслідків у вигляді смерті або інших тяжких наслідків. На практиці тлумачення цього оціночного поняття здійснюється органами досудового слідства та судом. Поняття «інші тяжкі наслідки» має оціночний характер і не $є$ чітко визначним у КК України. У теорії кримінального права відсутня єдина позиція щодо розуміння поняття «інші тяжкі наслідки», хоча це поняття зустрічається доволі часто (61 раз) у тексті диспозиції статей Особливої частини КК України. У $90 \%$ випадків воно вживається разом із іншими словосполученнями, що відображають суспільно небезпечні наслідки діяння - це «смерть особи» або «загибель людей».

Л.П. Брич зазначає, що «інші тяжкі наслідки» завжди мають альтернативний характер і обсяг цього поняття залежить від тих понять, що позначають суспільно небезпечні наслідки, в поєднанні 3 якими воно назване в диспозиції статті (частині статті) Особливої частини КК України. Як зазначають О.О. Дудоров та P.О. Мовчан коли в диспозиції кримінально-правової норми наслідки у вигляді загибелі людей (чи смерті особи) виступають єдиною альтернативою іншим тяжким наслідкам, зміст останніх має тлумачитися із застосуванням таких принципів тлумачення, як: 1) Ejusdem generis («того ж роду або класу»): якщо в тексті закону загальні слова йдуть за переліком конкретних предметів, осіб чи категорій, то загальні слова можуть 
означати лише предмети чи осіб тієї ж природи чи характеру, що і перераховані; 2) Noscitu ra sociis («той, що пізнається за супутнім»): якщо слово має декілька значень, його значення в законі з'ясовується за тими словами, які оточують його в контексті. Можна сформулювати таке правило тлумачення кримінального закону: в тих випадках, коли в статті КК України «загибель людей» (або «смерть особи») виступає єдиною альтернативою «іншим тяжким наслідкам», до змісту останніх можна відносити лише ті наслідки, які полягають у певній фізичній шкоді здоров'ю людини. Такої ж позиції дотримується і В.О. Навроцький ${ }^{12}$.

Користуючись цим правилом, можемо зазначити, що «інші тяжкі наслідки» в ст. 141 КК України варто визначати як такі, що заподіюють шкоду здоров'ю потерпілого, оскільки диспозиція статті в частині наслідків діяння сформульована як «смерть пацієнта або інші тяжкі наслідки» (альтернативний характер наслідків). Такою шкодою може бути спричинення середньої тяжкості або тяжких тілесних ушкоджень.

Суб'єкm злочину, передбачений ст. 141 КК України, є спеціальним. Ним може бути дослідник/співдослідник або інший працівник лікувально-профілактичного закладу, на базі якого за рішенням центрального органу виконавчої влади, що формує та забезпечує реалізацію державної політики у сфері охорони здоров'я, проводиться клінічне дослідження лікувального засобу, та який залучений до проведення клінічного дослідження.

Відповідно до Наказу МО3 № 690 «дослідник/співдослідник» - це лікар, який має достатню професійну підготовку та досвід лікування пацієнтів, знає правила належної клінічної практики та відповідні нормативно-правові акти. Дослідник несе відповідальність за проведення у місці дослідження клінічного випробування лікарського засобу. Якщо клінічне випробування проводиться групою осіб у певному місці проведення дослідження, один із дослідників визначається відповідальним керівником дослідницької групи і може називатися відповідальним дослідником ${ }^{13}$. Оскільки, лікар може бути притягнутий до кримінальної відповідальності за вчинення злочину, передбаченого ст. 141 КК України, то його теж потрібно відносити до категорії «медичних злочинів».

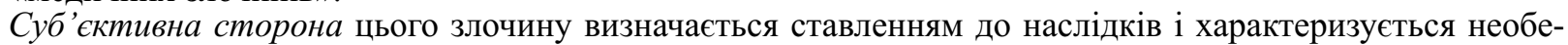
режністю ${ }^{14}$. Злочин, передбачений ст. 141 КК України, має матеріальний характер і вважається закінченим у момент настання наслідків, передбачених диспозицією цієї статті.

Однак не лише ст. 141 КК України стосується відповідальності щодо порушень при проведенні клінічних досліджень. Також ст. 321-2 КК України з назвою «Порушення встановленого порядку доклінічного вивчення, клінічних випробувань і державної реєстрації лікарських засобів» заслуговує на нашу увагу. Частина 1 ст. 321-2 передбачає відповідальність за умисне порушення встановленого порядку доклінічного вивчення, клінічних випробуваль лікарських засобів, фальсифікацію їх результатів, а також порушення встановленого порядку державної реєстрації лікарських засобів ${ }^{15}$.

У ст. 321-2 КК України основним безпосереднім об'єктом посягання є суспільні відносини, які виникають при доклінічному вивченні, клінічних випробувань лікарських засобів, а також державній реєстрації лікарських засобів. Частина 3 ст. 321-2 КК України передбачає також життя і здоров’я особи як додатковий обов 'язковий об' $є$ $\mathrm{Km}^{16}$.

Об 'єктивна сторона ст. 321-2 КК України характеризується такими діями, як: 1) порушення встановленого порядку доклінічного вивчення лікарських засобів; 2) порушення встановленого порядку клінічних випробувань лікарських засобів; 3) фальсифікація результатів доклінічного вивчення та клінічних випробувань лікарських засобів; 4) порушення встановленого порядку державної реєстрації лікарських засобів ${ }^{17}$. Аналогічно до ст. 141 КК України, ст. 321-2 має бланкетний характер.

Отже, відповідно до Закону України «Про лікарські засоби», який регулює правовідносини, що пов’язані зі створенням, реєстрацією, виробництвом, контролем якості та релізацією лікарських засобі, у Розділі II виокремлено такі етапи створення та випуску на ринок лікарських засобів: 1) доклінічне вивчення лікарських засобів - це хімічні, фізичні, біологічні, мікробіологічні, фармакологічні, токсикологічні та інші наукові дослідження з метою вивчення специфічної активності та безпечності лікарських засобів (ці дослідження проводяться на тваринах та регулюються ст. 6 Закону України «Про лікарські засоби», Наказом МО3 № 944 від 14.12.2009 «Про затвердження Порядку проведення доклінічного вивчення лікарських засобів та експертизи матеріалів доклінічного вивчення лікарських засобів»); 2) клінічні випробування лікарських засобів проводяться 3 метою встановлення або підтвердження ефективності та нешкідливості лікарського засобу (ст. 7 Закону України «Про лікарські засоби», Наказ МО3 № 690); 3) державна реєстрація лікарського засобу (ст. 9 Закону України «Про лікарські засоби», Постанова Кабінету Міністрів України від 26.05.2005 № 376 «Про затвердження Порядку державної реєстрації (перерєстрації) лікарських засобів і розмірів збору за їх державну реєстрацію»). Порушення норм, передбачених одним із цих нормативно-правових актів тягне за собою настання кримінальної відповідальності за ч. 1 ст. 321-2 КК України.

Суб' $є к m$ ст. 321-2 КК України - спеціальний; ним може бути особа, яка бере участь в доклінічному вивченні чи клінічному дослідженні лікарського засобу, державній реєстрації лікарського закладу ${ }^{18}$ (в частині клінічних випробувань суб'єкта варто визначати аналогічно ст. 141 КК України).

Суб 'єктивна сторона ст. 321-2 КК України характеризується умисним ставленням до діяння і необережністю до настання наслідків, передбачених у ч. 3 ст. 321-2 КК України ${ }^{19}$.

Проаналізувавши ці дві статті КК України бачимо, що із внесення у 2012 р. в КК України ст. 321-2 виникла штучна конкуренція цих двох норм в частині проведення клінічних випробувань лікарських засобів, зокрема, щодо ч. 3 ст. 321-2 КК України та ст. 141 КК України щодо проведення клінічних випробувань лікарських засобів без згоди досліджуваного, що спричинили наслідки у вигляді смерті чи інших тяжких наслідків. Це можна обгрунтувати тим, що «порушення встановленого порядку клінічних випробувань лікарських засобів» охоплює «проведення клінічних випробувань лікарських засобів без письмової згоди пацієнта 
або його законного представника». Тобто це можна визначити як конкуренцію загальної (ст. 321-2 КК України) та спеціальної (ст. 141 КК України) норми. Головною різницею в них є основний об'єкт кримінальноправової охорони.

Висновки. 3 метою уникнення подвійної кримінально-правової заборони одного діяння вважаємо за доцільне внести зміни до ст. 321-2 КК України, вилучивши з диспозиції ч. 1 діяння у формі «порушення встановленого порядку клінічних випробувань лікарських засобів». У свою чергу, сформулювати диспозицію ст. 141 КК України наступним чином: «Порушення порядку проведення клінічних випробувань лікарських засобів, зокрема проведення клінічних випробувань лікарських засобів без письмової згоди пацієнта або його законного представника, або стосовно неповнолітнього чи недієздатного, що спричинили шкоду здоров'ю або смерть пацієнту».

Також потрібно узгодити норми галузевого законодавства в частині проведення клінічних випробувань, узгодити між собою норми законів та підзаконних нормативно-правових актів із метою покращення процедури регулювання проведення клінічних досліджень лікарських засобів.

1 Кримінальний кодекс України: Закон України від 05 квітня 2001 р. № 2341-III (редакція від 16 січня 2020 р.). URL: https://zakon.rada.gov.ua/laws/show/2341-14

2 Науково-практичний коментар Кримінального кодексу України / А.М. Бойко та ін. ; ред.: М.І. Мельник, М.І. Хавронюк. Київ : Юридична думка, 2010. URL: http://yport.inf.ua/stattya-141-porushennya-prav.html

3 Там само.

4 Про затвердження Порядку проведення клінічних випробувань лікарських засобів та експертизи матеріалів клінічних випробувань і Типового положення про комісії з питань етики: наказ Міністерства охорони здоров'я України від 23 вересня 2009 p. № 690 (редакція від 31 грудня 2015 р.). URL: https://zakon.rada.gov.ua/laws/show/z1010-09

5 Конституція України : Закон від 28 червня 1996 р. № 254к/96-ВР (редакція від 01 січня 2020 р.). URL: https://zakon.rada. gov.ua/laws/show/254к/96-вр

6 Основи законодавства України про охорону здоров’я: Закон України від 19 листопада 1992 р. № 2801-XII (редакція від 16 січня 2020 р.). URL: https://zakon.rada.gov.ua/laws/show/2801-12

7 Цивільний кодекс України: Кодекс від 16 січня 2003 р. № 435-IV (редакція від 13 лютого 2020 р.). URL: https://zakon. rada.gov.ua/laws/show/435-15

${ }^{8}$ Про лікарські засоби: Закон України від 04 квітня 1996 р. № 123/96-BP (редакція від 01 січня 2019 р.). URL: https://zakon. rada.gov.ua/laws/show/123/96-вр

9 Про затвердження Порядку проведення клінічних випробувань лікарських засобів та експертизи матеріалів клінічних випробувань і Типового положення про комісії з питань етики: наказ Міністерства охорони здоров'я України від 23 вересня 2009 p. № 690 (редакція від 31 грудня 2015 р.). URL: https://zakon.rada.gov.ua/laws/show/z1010-09

10 Науково-практичний коментар Кримінального кодексу України / А.М. Бойко та ін. ; ред.: М.I. Мельник, М.I. Хавронюк. Київ : Юридична думка, 2010. URL: http://yport.inf.ua/stattya-141-porushennya-prav.html

11 Там само.

12 Дудоров О.О., Мовчан Р.О. Кримінально-правове поняття «інші тяжкі наслідки»: проблеми тлумачення та вдосконалення законодавства. Юридичний науковий електронний журнал. 2015. № 1. С. 162-170. С. 163

13 Про затвердження Порядку проведення клінічних випробувань лікарських засобів та експертизи матеріалів клінічних випробувань і Типового положення про комісії з питань етики: наказ Міністерства охорони здоров'я України від 23 вересня 2009 р. № 690 (редакція від 31 грудня 2015 р.). URL: https://zakon.rada.gov.ua/laws/show/z1010-09

14 Науково-практичний коментар Кримінального кодексу України / А.М. Бойко та ін. ; ред.: М.I. Мельник, М.I. Хавронюк.

Київ : Юридична думка, 2010. URL: http://yport.inf.ua/stattya-141-porushennya-prav.html

15 Кримінальний кодекс України: Закон України від 05 квітня 2001 р. № 2341-III (редакція від 16 січня 2020 р.). URL: https://zakon.rada.gov.ua/laws/show/2341-14

16 Науково-практичний коментар до статті 321-2 Кримінального кодексу України. Науково-практичний коментар від 25.07.2015. Ліга Закон. URL: https://ips.ligazakon.net/document/view/KK007297

17 Там само.

18 Там само.

19 Там само.

\section{Резюме}

Шкодяк А.І. Кримінально-правова оцінка порушення правил проведення клінічних досліджень лікарських засобів.

У статті досліджено елементи двох складів злочинів, які встановлюють кримінальну відповідальність за порушення під час проведення клінічних досліджень лікарських засобів, а саме ст. 141 та ст. 321-2 Кримінального кодексу України. Автором було досліджено елементи цих двох складів злочинів, висвітлено питання особи потерпілого. Автор зазначила неузгодженість нормативно-правових актів щодо особи досліджуваного. Також було визначено суб'єкт вчинення цих злочинів в частині проведення клінічних досліджень лікарських засобів. Підкреслюється, що ці дві статті можуть співвідноситися як загальна та спеціальна норма. Було запропоновано внести зміни до цих двох статей 3 метою уникнення подвійної кримінально-правової заборони одного й того ж діяння.

Ключові слова: клінічні дослідження, пацієнт, кримінальна відповідальність, досліджуваний, лікарський засіб, лікар.

\section{Резюме}

Шкодяк А.И. Уголовно-правовая оценка нарушения правил проведения клинических исследований лекарственных средств.

В статье исследованы элементы двух составов преступлений, устанавливающие уголовную ответственность за нарушения при проведении клинических исследований лекарственных средств, а именно ст. 141 и ст. 321-2 Уголовного кодекса Украины. Автором были исследованы элементы этих двух составов преступлений, освещены вопросы личности потерпевшего. Автор отметила несогласованность нормативно-правовых актов в отношении лица испытуемого. Также был определен субъект 


\section{Кримінальне право та кримінологія}

совершения этих преступлений в части проведения клинических исследований лекарственных средств. Подчеркивается, что эти две статьи могут соотноситься как общая и специальная норма. Было предложено внести изменения в эти две статьи во избежание двойного уголовно-правового запрета одного и того же деяния.

Ключевые слова: клинические испытания, пациент, уголовная ответственность, исследуемый, лекарственное средство, врач.

\section{Summary}

Alona Shkodiak. Criminal and legal evaluation of rules of conducting clinical research of medicinal products violations.

The article investigates the two legal components of crime that establish criminal liability for violations during clinical research of medicines. They are Art. 141 of the Criminal Code of Ukraine, which establishes responsibility for conducting clinical trials of medicines without the written consent of the patients or their legal representative, or in cases with minors or legally incapable persons if these actions caused the death of the patient or other grave consequences, and Art. 321-2 of the Criminal Code of Ukraine, which in part 1 envisages responsibility for intentional violation of the established procedure of preclinical study, clinical trials of medicines, falsification of their results, as well as violation of the established procedure of state registration of medicines.

In particular, the article studies the issue of the person under the study (research subject) who is the victim of these crimes. The author notes that there is a disagreement in the regulations concerning the issue of who can be subject of research. In the Law of Ukraine "On Medicines", such persons are adults, minors, underage persons, persons who are declared incapacitated by the court or whose civil capacity is limited due to mental illnesses. The MoH Decree No. 690 defines subjects of study as legally capable adults, minors, underage persons and incapacitated of persons. The lack of a procedure to include persons with disabilities raises questions about the possibility of involving such persons in clinical trials.

The objective side of the commission of these two crimes was investigated, the subject of these crimes was identified. Both in Art. 141, and in Art. 321-2 of the Criminal Code of Ukraine in the part of conducting clinical research of medicines, the subject is special; it can be a researcher/co-researcher (doctor) or other employee of a medical-prophylactic institution, at the facilities of which - by decision of the central body of executive power which forms and provides implementation of state policy in healthcare - a clinical trial of the medicine is conducted and which is involved in conducting a clinical research.

The author notes that these two articles can correlate as general and special norm, which differ in the main subject of criminal and legal protection. The author proposed to amend these two articles in order to avoid a double criminal prohibition on one act.

Key words: clinical research, patient, criminal liability, experimental, medicinal drugs, doctor. 